\title{
Ulf Boëthius
}

\section{"Hemma längtar jag bort, borta längtar jag hem."
Andra världskrigets finska krigsbarn i svensk barn- och ungdomslitteratur

\begin{abstract}
Finnish child refugees of the Second World War in Swedish literature for children and youth. During and after the Second World War Sweden received around 70000 Finnish war children. It was by far the biggest of all contingents of refugees during the war. The (often only Finnish speaking) children were placed in Swedish foster homes or in children's homes. Most of them were sent back to Finland after the war but a big group also stayed with their foster parents. The movements from one home to another (some made this journey on more than one occasion) made many of them feel lonely, deserted and abandoned. In this paper I am going to discuss how the Finnish war children are depicted in Swedish books for children and youth from the war years up until today. After a discussion of the fluctuations of interest in the Finnish child refugees in Swedish children's books I will focus on how they have been depicted. What aspects have been focused on and what problems have been selected (or neglected) in different books at different times? I will also show how the treatment of the subject has been governed by a whole set of different factors: the age of the addressees, the choice of genre, the expanding research on the Second World War (and more specific the Finnish war children), the public debates on the treatment of (also contemporary) war refugees and not least the changes of the Swedish literature for children and youth, from the 1960s focusing more on social problems and developing towards a greater realism
\end{abstract}

Keywords: Second world war, Finnish children war refugees, Finnish children's literature

Varje år anländer tusentals ensamma flyktingbarn till Sverige - tyvärr utan att vara särskilt välkomna. Barn som tvingats lämna sitt land efter att ha upplevt krig, våld och andra fasor är emellertid ingen ny företeelse. Under andra världskriget tog Sverige emot cirka 70000 finska krigsbarn - den största flyktinggruppen under hela kriget. 
Dessa barn behandlades av olika skäl med en helt annan generositet än de judiska flyktingbarn som under krigets första år också försökte komma till Sverige. Flyktingar från de nordiska länderna hade i praktiken förtur (Byström 2006, 24f). Medan de judiska flyktingarna avvisades direkt vid gränsen (sedan de svenska myndigheterna begärt att de skulle ha ett J i passen) togs de finska barnen emot med öppna armar.

Ändå hade de det inte lätt. De kom i regel ensamma utan föräldrar eller andra anhöriga och identifierades enbart genom en namnlapp om halsen. Majoriteten av barnen var under tio år. Somliga var inte ens ett år gamla när de skickades iväg (Kavén 2004, 198). Ingen visste var han eller hon skulle hamna.

De flesta kom från arbetarhem (Ekberg 1999, 199). I Sverige togs de för det mesta om hand av (ofta välbeställda) fosterfamiljer men många placerades på barnhem. Syskon reste tillsammans men skildes efter ankomsten ofta från varandra. Många barn förstod inte svenska och de som lärde sig riskerade i stället att förlora sin förmåga att tala finska. Krigsbarnen utsattes för svåra känslomässiga påfrestningar. Allra värst var kanske separationerna - först från de biologiska föräldrar och sedan, när de måste åka tillbaka, från fosterföräldrarna.

I den här uppsatsen skall jag undersöka hur de finska krigsbarnen har skildrats i den svenska barn- och ungdomslitteraturen från krigsåren och fram till idag. Vilka problem har författarna ställt i fokus, hur har de behandlat sitt ämne - och varför är deras bilder ofta så olika? Ett antal bakomliggande faktorer kan förmodas ha spelat en viktig roll. En sådan är barnlitteraturens särskilda och historiskt föränderliga normsystem. Författare förväntas i allmänhet behandla sitt ämne på ett annat vis när de skriver för barn än när de skriver för vuxna. För femtio år sedan borde berättelserna också vinklas på ett sätt för pojkar och på ett annat för flickor - och dessutom måste författarna ofta välja någon av pojk- eller flickbokens särskilda undergenrer, något som ytterligare begränsade perspektivet. Att små barn måste tilltalas på ett annat sätt än de som är lite äldre var också en självklarhet - och är det än idag.

Vidare är valet av berättarteknik (som delvis styrs av de ovan berörda valen) av betydelse. En allvetande berättare ger till exempel helt andra möjligheter att behandla ämnet än ett barn som berättar i första person. En tillbakablickande berättelse kan ge utrymme för andra tankar och känslor än en samtidsskildring. Viktiga är också ett antal kontexter: barnlitteraturens förändringar, den ökade utgivningen av självbiografier och romaner för vuxna om de finska krigsbarnen, den alltmer omfattande forskningen kring andra världskriget (inklusive 
flyktingarna) samt de olika invandrardebatterna under den period det gäller. Alla dessa olika faktorer har barnlitteraturförfattarna i större eller mindre utsträckning varit tvungna att förhålla sig till när de skildrat de finska krigsbarnen.

\section{Barntransporterna}

Barntransporterna till Sverige inleddes i december 1939 - två veckor efter det finska vinterkrigets utbrott. Den på privat initiativ grundade organisationen Centrala Finlandshjälpen skötte transporterna och uppslutningen blev mycket stor (Carlquist 1971, 16f). Den svenska parollen under kriget löd som bekant: "Finlands sak är vår". Sammanlagt anlände cirka 9000 barn under vinterkriget. De flesta av dessa skickades tillbaka efter fredsslutet i mars 1940 (Ekberg 1999, 199).

Men när Finland i juni 1941 ställde sig på Hitlers sida i anfallskriget mot Sovjet började barntransporterna på nytt, nu i mycket större skala än tidigare. Under den första stora flyktingvågen 1941-1942 anlände cirka 21000 barn, under den andra som ägde rum 1944-1945, kom cirka 31000 (Kavén 2004, 105). Dessutom sändes många på privat väg. Eftersom barn också återvände under lugnare perioder gjorde somliga två resor och ibland tre. De cirka 70000 som sammanlagt transporterades till Sverige (Käppi 2003, 35) utgjorde en hel årskull finska barn. Många av dem återvände aldrig. Man räknar med att cirka 10000 stannade i Sverige för gott (Kavén 2004, 12, 186).

Det fanns redan från början ett visst motstånd i Finland mot barntransporterna. Många ansåg att materiell och ekonomisk hjälp skulle vara av större betydelse. Under fortsättningskriget blossade kritiken upp igen, både i Finland och Sverige. Var det verkligen bra för barnen att skickas iväg? När kritiken växte införde de finska myndigheterna censur: i januari 1942 förbjöds all negativ publicitet kring barntransporterna (Kavén 2004, 87ff).

Tystnaden bröts först 1946, då den finska regeringen krävde att alla finska flyktingbarn skulle sändas tillbaka. Nu utbröt en intensiv debatt samtidigt som en serie utdragna rättsprocesser inleddes - många fosterföräldrar ville behålla sina barn. Den centrala frågan var om barnen skulle ta skada av att sändas tillbaka. Det trodde inte den auktoritet som de finska myndigheterna anlitade, psykiatriprofessorn Martti Kaila (Kavén 2004, 142ff). Men alla var inte lika övertygade och debatten fortsatte in på 1950-talet.

Därefter blev det under lång tid tyst om de finska krigsbarnen. Först i slutet av 1970-talet dök de upp igen - och nu var det krigs- 
barnen själva som tog till orda. Annu Edvardsen bröt tystnaden med den uppmärksammade boken Det får inte hända igen: finska krigsbarn 1939-1945 (1977). Edvardsen, som själv två år gammal sänts till Sverige, hade intervjuat både tidigare krigsbarn och personer som medverkat vid transporterna. Budskapet framgick redan av titeln: detta får inte hända igen. Det stora flertalet av dem hon intervjuat led av "rotlöshet, bristande självkänsla, kontaktlöshet och en inre oförklarlig otrygghet" (Edvardsen 1977, 5).

Sedan dess har det utkommit ett stort antal böcker om de finska krigsbarnen. Bland dessa finns två större vetenskapliga undersökningar av hur de påverkades av transporterna. Barnläkaren Eila Räsänen (1990) ger en förhållandevis positiv bild medan resultaten i psykologen Lillemor Lagnebros avhandling (1994) pekar i rakt motsatt riktning.

\section{Krigsbarnsböckerna}

Samtidigt har det kommit en allt stridare ström av skönlitterära berättelser av forna krigsbarn. Krigsbarnsböckerna har nu blivit så många att de bildar en egen genre (Virtala 2004, 19). Den finlandssvenska litteraturforskaren Irene Virtala redovisade i sin uppsats Tystnaden talar: om finska krigsbarn i skönlitteraturen (2004) inte mindre än 70 böcker, de allra flesta skrivna på svenska av kvinnliga författare (Virtala 2004, 78). Sedan dess har det (som bland annat framgår av bibliografin på Riksförbundet Finska Krigsbarns hemsida) publicerats ytterligare ett tjugotal titlar. Det har också kommit ännu en litteraturvetenskaplig studie, Ylva Uotilas pro-gradu-avhandling Med namnlapp om halsen: fyra finlandssvenska krigsbarnsromaner (2005). Men den ende som ägnat just barnböckerna om finska krigsbarn särskild uppmärksamhet är den svenske forskaren Staffan Thorson, som i Barnbokens invandrare (1987) diskuterar ett par av dem (205f).

Krigsbarnsböckerna har en rad teman gemensamma - de viktigaste är relationerna till föräldrar och fosterföräldrar samt frågan om den egna identiteten (Virtala 2004, 79ff; Uotila 2005, 58ff). Men man kan också urskilja en gemensam grundberättelse. Denna börjar med barnens liv i Finland och deras upplevelse av kriget. Därefter kommer separationen från föräldrarna, resan till Sverige, det första mötet med fosterföräldrarna och den ibland svåra integrationen i den svenska miljön. Grundberättelsens andra del handlar om återvändandet till Finland. Den inleds med separationen från fosterföräldrarna, tillbakaresan och ankomsten till de biologiska föräldrarna. Så kommer ett mer eller mindre långt försök till återanpassning - innan 
berättelsen slutar med antingen en (mer eller mindre lycklig) integrering i den finska familjen eller ett återvändande till fosterföräldrarna i Sverige.

Det intressanta är förstås grundberättelsens olika variationer. Hur ser variationerna ut i barnböckerna? Vilka moment har man skjutit i förgrunden, vilka teman har stått i centrum och hur har dessa behandlats?

\section{Barnböcker om finska krigsbarn}

Barnböckerna om finska krigsbarn är förhållandevis få. Jag har bara funnit ett tiotal böcker, alla skrivna av kvinnliga författare. Samtliga handlar dessutom (med ett enda undantag) om flickor - de finska krigsbarnen har för det mesta uppfattats som en kvinnlig angelägenhet. Fem av böckerna är flickböcker, två kan rubriceras som ungdomsböcker (med flickor i huvudrollerna), två är bilderböcker, en är en mellanåldersbok och den elfte och sista är en "nallesaga" för mindre barn.

Utgivningen av barnböcker om finska krigsbarn står egendomligt nog i omvänd proportion till utgivningen av vuxenböcker i samma ämne. Mer än hälften av barnböckerna är publicerade under 1940talet - när man får leta med ljus och lykta efter en vuxenbok. Men under de senaste tre decennierna, när vuxenböckerna om krigsbarn exploderat, har det bara kommit fyra barnböcker.

Varför har de sentida författarna i så liten utsträckning skrivit för barn? Man kunde vänta sig motsatsen med tanke på att ensamma och övergivna barn sedan länge är ett huvudtema i barnlitteraturen. Kanske kan en orsak vara att författarna i första hand riktat sig till andra krigsbarn, att de uppfattat sina böcker som repliker i ett samtal om gemensamma erfarenheter. De forna krigsbarnen har uppenbarligen haft ett behov av att tala med varandra. 1992 skapades i Sverige Riksförbundet Finska Krigsbarn och motsvarande organisationer har växt fram också i Finland och Danmark (Ortmark-Almgren 2003, 9f).

\section{Den första perioden: det svenska mottagandet i centrum}

Man kan urskilja fyra olika perioder i utgivningen av barnböcker om finska krigsbarn. Den första omfattar själva krigsåren, den andra det första decenniet efter kriget, den tredje decennierna mellan 1955 och 1985 medan den fjärde och sista sträcker sig från 1980-talets mitt och fram till idag. 
Den första perioden domineras av berättelser som ställer det svenska mottagandet av krigsbarnen i centrum. Det är fråga om tre flickböcker som alla utspelas i välbärgade medelklassmiljöer. Maja Jäderin-Hagfors Klassens fosterbarn (1941), handlar om hur en svensk skolklass tar sig an två finska krigsbarn under vinterkriget. I samma författares Två små flyktingar (1944) förekommer också ett finskt krigsbarn, men bara i en biroll (huvudpersonerna har en annan bakgrund). Den tredje boken är Anna-Lisa Lundkvists Vägen till Kanarieön (1945). Här handlar det precis som i Klassens fosterbarn om två finska krigsbarn; återigen är det en flicka och hennes yngre bror som skall tas om hand. (Det kan tilläggas att även Astrid Lindgren skrev en kortare berättelse med samma tema, "Jorma och Lisbet", publicerad först i Astrid Lindgren-sällskapets medlemsblad nr 25, 2009.)

Låt oss titta lite närmare på Klassens fosterbarn och Vägen till Kanarieön. Här är det barn i de svenska mottagarfamiljerna som är de egentliga huvudpersonerna. De finska krigsbarnen kommer i andra hand, även om historierna är uppbyggda kring dem. I Klassens fosterbarn får vi följa den tolvåriga Helmi och hennes sjuårige bror Ilmari från det att de i januari 1940 kommer till Sverige till dess att de efter vinterkrigets slut reser tillbaka igen. Kriget utgör således fonden till det hela men syskonen tycks inte ha varit med om så otäcka saker som de vuxna fruktar. Omgivningen tror att Helmi tiger därför att hon traumatiserats av kriget (bokens ord är "komplex"). Men det har hon inte: hennes tystnad är i stället en protest mot att hon skickats iväg till Sverige mot sin vilja. Hon hade velat stanna kvar och kämpa för sitt fosterland som smålotta (precis som Unnerstads Aune. Se s. 25). Den allvetande berättaren har stor förståelse för hennes protest. Inte heller Anitra, bokens svenska huvudperson skulle vilja bli bortskickad till ett annat land om det blev krig: "jag skulle bli tokig då, tror jag" (83).

Samtidigt framstår beslutet att sända Helmi och hennes bror till Sverige som riktigt. Mamman är död sedan många år och pappan, som har en gård nära fronten, vågade inte ha barnen kvar. Han kunde knappast heller - husföreståndarinnan flyttade vid vinterkrigets utbrott. Och när det är krig är det andra som bestämmer: då måste man bara lyda order, säger Anitras pappa (83).

Boken berör krigsbarnens problem med lätt hand. Helmi och Ilmari har inga språksvårigheter - de talar båda svenska. Anitra påpekar dock att andra har det: "Helmi, jag tänker på dom barn som verkligen inte förstår språket, mitt språk menar jag, dom har det nog inte lätt så här i främmande land?" (112). Ett annat problem som boken tar upp är omgivningens nyfikenhet. Helmi har ibland känt sig 
som ett utställningsföremål: "Hela trakten hade folkvandring för att titta på oss." (112) Ett tredje problem som skymtar, även om det inte görs någon stor sak av det, är det instabila i barnens situation. När Inkeri och Ilmari så småningom får flyttat hem till Anitra är det deras tredje fosterfamilj. Separationerna betraktas dock inte som något större problem. Det sägs ingenting om avskedet från fadern i Finland eller hur det var att lämna de tidigare fosterfamiljerna. Inte heller avskedstagandet från Anitra och hennes familj är särskilt sorgligt. Vistelsen i Sverige har ju varit ganska kort. Dessutom följer Anitras faster med (hon skall bli hushållerska åt fadern) och Anitra själv och hennes bästa vän lovar att hälsa på nästa sommar.

Klassens fosterbarn handlar inte bara om omhändertagandet av flyktingbarn. Lika viktig är bokens diskussion om huruvida man skall skydda barn från verklighetens mörka sidor eller inte. Anitras föräldrar (bosatta på Östermalm i Stockholm) anser att barn skall slippa höra talas om nöd, sorg och lidanden. Därför vill de inte tala med henne om det det pågående kriget. Bokens budskap är att de har fel. För det första är det en omöjlighet att hålla barnen utanför i ett modernt samhälle med radio och tidningar. För det andra är det själviskt att i all evighet försöka hålla kvar sina barn i småbarnstadiet. Dessutom mår barnen inte bra av placeras i "glasskåp" (62): "jag börjar känna det som om ni satte på mig för trånga kläder, jag tycker det är som om jag inte kunde andas riktigt", säger Anitra (26).

Bokens barnsyn är häpnadsväckande modern. Författaren vill visa att tolvåriga barn är långt mera vuxna än deras fostrare tror. Anitra (och även Helmi) får under handlingens gång demonstrera att en tolvårig flicka inte bara tål att konfronteras med krigets verklighet utan också att kan vara initiativrik, ansvarskännande, klok och handlingskraftig. Det är Anitra som tar initiativet till att klassen skall ta sig an två finska krigsbarn. Och det är hon som så småningom får den protesterande Helmi att tala och som på eget initiativ bjuder in barnen till sitt eget föräldrahem när deras tidigare fostermamma inte kan ta hand om dem längre.

Anitras föräldrar får också inse att de haft fel. "Vi har inte alls uppfostrat Anitra rätt, vi ha nästan satt henne under en glaskupa", säger den ångerköpta modern. "Det skulle i alla fall komma den dag då hon eller någon annan slagit sönder den och då kanske hon inte alls tålt den kalla luft som svept omkring henne. Det är nog bara nyttigt att så småningom bli en smula härdad mot livet." (84) Det är en barnsyn som både pekar bakåt, mot en äldre föreställning om kompetenta och ansvarstagande barn (Boëthius 2004, 248), och framåt, mot 1970-talets samhällsengagerade barn. Däremot står den i skarp 
motsättning till det lekfulla och oansvariga barn som kom att dominera efter krigsslutet.

Även Anna Lisa Lundkvist ställer en svensk mottagarfamilj i fokus. I Vägen till Kanarieön (som är hennes debutbok) anländer den tioåriga Karita och hennes fyraårige bror Arno från krigets Finland till en vit herrgårdsbyggnad någonstans i Sverige. Pappan och äldste brodern har båda stupat i kriget och mamman är sjuk. I herrgården bor den elvaåriga Tim och hennes föräldrar. Krigsbarnen skall bo i Tims rum - själv får hon flytta till ett annat. Vägen till Kanarieön är inte samma solskenshistoria som Klassens fosterbarn. Tim är redan från början avogt inställd till nykomlingarna och det är hennes själviskhet som är bokens huvudtema. Flyktingbarnen (som talar svenska) är bleka och magra och har upplevt hemska saker. Den tioåriga Karita är ännu mera vuxen än Jäderin-Hagfors Anitra. Hon för ett djupsinnigt samtal om rätten (och skyldigheten) att döda när det är krig med enstöringen Roderiksson (som en gång dödat en människa av våda) - och om möjligheten att få förlåtelse när man berövat någon livet. Men Tim kan inte acceptera Karita. "Hon glömde att hon själv ägde hem och föräldrar och ett fredligt lyckligt land att bo i", kommenterar den allvetande berättaren. "Allt det som Karita saknade." (61)

Konflikten kulminerar sedan Tims bäste vän, Svante, skvallrat för Karita om deras gemensamma leklandskap vid tjärn i skogen. Där har Tim sin egen lilla ö, Kanarieön. Även den lille Arno får höra talas om Kanarieön. När Tim lurar i honom att ett par kanariefåglar hålls inspärrade i sin bur av en elak häxa släpper han ut dem så att de kan flyga till den paradisiska Kanarieön. När han sedan förstår att de kanske riskerar att dö ger han sig iväg för att leta rätt på dem - och försvinner i nattens mörker. Karita förstår att det är Tim som har lurat iväg honom och säger att det är hon som bär skulden om det skulle hända Arno något.

Men efter detta syndafall vänder berättelsen. Tim känner skuld och ånger. När en av kanariefåglarna återkommer tolkar Karita detta som ett tecken från en högre makt: de kommer att hitta Arno. Och de gör man också - Tim, som givit sig ut för att söka, knackar på hos Roderiksson och finner Arno. Nu förlåter Karita den gråtande Tim och de omfamnar varandra.

Hela naturen deltar i denna färd från syndafall och skuld till återupprättelse och försoning. När Arno går vilse är det hällregn och snart blir det också natt och mörker. När han återfinns (på själva pingstdagens morgon) är det tvärtom strålande sol, allt glittrar och glänser och vårfåglarna stämmer upp "sin tusenstämmiga kör". 
Skogen är som förtrollad, säger Roderiksson. "Så ren och ljus som en paradisets ängd." (111) Det är som om Guds kärlek denna pingstdagsmorgon sprider sig inte bara i hela naturen utan också i människornas hjärtan. "Det var pingstdag och helg långt inne i Tims hjärta." (144) Nu kommer också glädjen tillbaka, alla kan skratta igen. "Det här är precis som i kyrkan", sammanfattar Tim och knäpper sina händer (152).

Så utvecklas Anna Lisa Lundkvists krigsbarnsberättelse till ett universellt drama om skuld och försoning med religiösa (antroposofiska) förtecken. (Lundkvist har översatt ett stort antal av Rudolf Steiners skrifter.) I detta perspektiv blir den avslutande upplysningen att Karitas och Arnos finska mamma skall komma och hälsa på till sommaren av underordnad betydelse. Viktigare är att den moraliska och existentiella ordningen har återupprättats.

\section{Två undantag}

Två böcker utgivna under den första perioden avviker dock från mönstret. Båda är skrivna av författare med finlandssvensk bakgrund, den ena av Edith Unnerstad (född i Finland) och den andra av Solveig von Schoultz, känd finlandssvensk vuxenförfattare.

I Unnerstads Pikku-Lotta (1941) är barntransporterna ett sidotema. Boken, som inte (som man kunde tro av titeln) är en flickbok utan en realistisk familjeskildring för ungdom, utspelas under det finska vinterkriget. Den handlar om hur bomberna över Helsingfors tvingar en sjubarnsfamilj att fly ut på landsbygden. Möjligheten att resa till Sverige (där familjen har släktingar) aktualiseras tidigt i boken och den svenska Finlandshjälpen nämns flera gånger. Till sist evakueras mamman (som är sjuk) tillsammans med de minsta barnen - fadern är inkallad.

Det är alltså enbart krigsbarnsberättelsens första del som skymtar i Pikku-Lotta. Någon kritik mot barntransporterna förekommer inte och det är bara den patriotiska och ansvarstagande Aune som, när hon väljer att stanna kvar och arbeta som smålotta ("pikku-lotta"), får uppleva det smärtsamma i att slitas "loss från föräldrar och syskon" (162).

Också Solveig von Schoultz' Nalleresan (1944, illustrerad av Tove Janson) anlägger ett finskt perspektiv. Här förvandlas barntransporterna till en munter saga (i tredje person) om levande dockor och nallar som bestämmer sig för att resa till Sverige där deras "mammor" redan finns. Leksakerna får genomgå samma procedur som krigsbarnen: först läkarbesök, sedan resa till Sverige i flygmaskin och båt, desinficering i karantän och slutligen resa med tåg till Dalarna. 
Det är alltså själva transporten som står i centrum. Om krigets fasor får vi ingenting veta i denna småbarnsbok och den allvetande berättaren förskonar också läsaren från de lidanden som var förknippade med transporterna. Här förekommer varken plågsamma separationer eller övergivenhetskänslor, resan görs till ett spännande äventyr och boken slutar med dockornas och nallarnas glada återförening med "mammorna" i Sverige.

\section{Den andra perioden: återvändandet till Finland}

Först efter kriget blir krigsbarnen själva huvudpersoner i barnböckerna. De första berättelserna av detta slag är, som Thorson noterat (1987, 206), Aili Konttinens När Inkeri kom hemifrån Sverige (1949) och Christina Söderling Brydolfs Sirpa (1954). Båda är flickböcker. Konttinens bok är en översättning från finska; originalet publicerades 1947. I dessa två böcker, som representerar krigsbarnsböckernas andra period, står en helt annan del av grundberättelsen i fokus: den smärtsamma separationen från de svenska fosterföräldrarna och den svåra återanpassningen till den ursprungliga familjen. Båda skrevs under den period då de finska myndigheterna krävde att krigsbarnen skulle sändas tillbaka.

Det finns så många likheter mellan böckerna att man är frestad att läsa Sirpa som ett svar på Konttinens berättelse. Ingen gör anspråk på att vara självbiografisk eller dokumentär. Inkeri, som är sex när hon i bokens början sänds tillbaka till Finland, var bara två när hon kom till Sverige, medan Sirpa, nu fjorton, bara var ett år gammal. Båda har behandlats som prinsessor av sina välbeställda fosterföräldrar - som inte har några egna barn. De biologiska föräldrarna är däremot i båda böckerna fattiga bönder som lever långt ute på den finska landsbygden med sina övriga barn (i Sirpas fall är det bara ett). Huvudpersonerna kan varken känna igen sina föräldrar eller sina syskon när de kommer tillbaka till sina forna hem - och de förstår inte deras finska.

Återanpassningen är särskilt svår för Inkeri. Hon blir så småningom mer eller mindre apatisk - precis som många flyktingbarn i Sverige idag. Hon äter inte, hon gråter om nätterna och om dagarna sitter hon bara tyst $i$ ett hörn och stirrar med tomma ögon och längtar efter sin älskade fostermamma. Förändringen kommer inte förrän Inkeri varit i Finland hela hösten. Under vintern föds det plötsligt ett föl på bondgården. Detta föl blir Inkeris övergångsobjekt: kärleken till fölet gör att hon successivt anpassar sig. Nu bryter hon tystnaden och börjar tala finska. Men hon vill fortfarande komma tillbaka 
till Sverige - trots att hon inte får ta med fölet dit. Det är först när mamman äntligen kommer (efter nästan ett helt år) som Inkeri (som nu inte längre kan forma svenska meningar) i det avgörande ögonblicket ändrar sig: hon kan inte lämna sina finska föräldrar och sitt älskade föl.

Den allvetande berättaren finner uppenbarligen detta beslut riktigt. "Men Inkeri var bara ett barn. I dag ville hon ett, i morgon ett annat", kommenterar berättaren när Inkeri envist håller fast vid kravet att få komma tillbaka till Sverige (136). Framför allt är boken dock en inträngande psykologisk skildring som låter läsaren uppleva inte bara Inkeris kluvna känslor utan också sorgen hos både den biologiska modern (som hon först avvisar) och den (barnlösa) svenska fostermamman (som får återvända till Sverige utan Inkeri).

Sirpas anpassning går mycket fortare än Inkeris - trots att hon levt i Sverige i tretton år och (i motsats till Inkeri) inte har en aning om att hon har finska föräldrar. Dessutom blir hon kidnappad tillbaka till Finland av en okänd man (som säger sig vara hennes morbror). Likafullt känner hon redan vid första mötet (föräldrarna är finskspråkiga men talar även svenska) hur hon och den biologiska familjen "smälte ihop till den enhet de av naturen var" (86). Det är bara när hon på båten till Finland får reda på att hon har finska föräldrar som hon ett ögonblick grubblar över sin identitet: "Vem var hon egentligen? En namnlös flicka mitt ute på havet utan hem." (74)

Men efter mötet med föräldrarna slutar hon grubbla och redan efter en månad är hon på väg att finna sig till rätta med sitt nya liv. Anpassningen underlättas av att hon blir kär: den unge man som hon möter i slutet av boken utgör en motsvarighet till Inkeris föl, med den skillnaden att Sirpa då redan för längesedan bestämt sig för att stanna. Liksom Inkeri får hon nämligen välja. Men här sker ingen dramatisk omkastning som i Konttinens bok. När de svenska fosterföräldrarna anländer efter nästan ett år vet vi sedan länge att Sirpa inte kommer att följa med.

Detta har att göra med att den allvetande berättaren är så angelägen att övertyga läsaren om att det är rätt att skicka tillbaka de finska krigsbarnen. Och detta motiveras inte bara psykologiskt (som hos Konttinen) utan i ännu högre grad ideologiskt. Det är inte bara det att de biologiska föräldrarna har "sin naturliga rätt" (69), Sirpa känner det också som om hon vore skyldig dem någonting: "Medan far hade varit ute i kriget och försvarat sitt land, medan han hade förlorat sin arm och synen på det ena ögat och suttit i fångenskap, hade hon, Sirpa, i ett främmande land levt ett lugnt och ombonat, bekymmersfritt och tanklöst liv." (86) Hon vill "gottgöra och avbetala" (73) 
genom att delta i föräldrarnas hårda arbete med gården - detta är en av de viktigaste anledningarna till att hon stannar.

\section{De tredje och fjärde perioderna}

Efter Sirpa inleds den tredje perioden i utgivningen av böcker om de finska krigsbarnen. Det är en period av tystnad. Under tre decennier, mellan 1954 och 1986, utkommer det inga böcker alls. Tystnaden bryts först med Sigbritt Eklunds Pojken med kepsen (1986). Men denna läsa-lätt-bok om en finsk pojke som tas om hand av en svensk familj vid Torne älv under några månader hösten 1944 är inte representativ för den fjärde och sista period som nu inleds (och som vi alltjämt befinner oss i). Den är nämligen fiktiv (i likhet med merparten av de tidigare böckerna), medan majoriteten av de barnböcker som publicerats under de senaste decennierna varit dokumentära och självbiografiska.

Typiska är två bilderböcker, Veronica Leos Ekorrögon (1990) och Gunilla Bönners Impi från Soumussalmi (1999). Författarna har också

gjort illustrationerna. Båda är tillbakablickande och berättade i första person av berättare som (enligt paratexterna) själva upplevt det som skildras. De vill samtidigt informera sina läsare om vad som hände och ger båda i efterskrifter upplysningar om kriget och om barntransporterna.

En följd av denna undervisande ambition är att författarna berör praktiskt taget alla moment i grundberättelsen, alltifrån kriget i Finland och vistelsen i Sverige till återkomsten till de biologiska föräldrarna. Tonvikten läggs emellertid lite olika. Veronica Leo ägnar sålunda stort utrymme åt själva kriget med bombanfall, förstörelse och tyst väntan i skyddsrummen. Hon berättar mestadels i ett närhetsskapande presens och de korta meningarna får ofta en rad var (som i dikter). Detta underlättar läsningen för mindre barn samtidigt som de täta pauserna ger utrymme för reflektion och eftertanke. Författaren lägger stor vikt vid berättarjagets estetiska sensibilitet: barnet i Ekorrögon finner skönhet i både i glassplitter och i brinnande städer. I dessa episoder (och de bilder som illustrerar dem) möter vi den framtida konstnären: bokens författare är som bekant en framstående bilderboksskapare.

Krigsbarnens problem tonas dock ner. Huvudpersonen behöver ingen namnlapp om halsen, man känner igen henne ändå. Separationerna framstår inte heller som något större problem: Veronica Leo är åtta år när hon kommer till Sverige, hon kan svenska och skickas tillbaka redan efter fyra månader. I sitt Efterord understryker hon 
emellertid att många hade det mycket värre: det fanns barn som inte kände igen sina föräldrar och som helt förlorat sitt språk.

I slutet av 1980-talet, strax innan Ekorrögon publicerades, ökade antalet flyktingar i Sverige starkt. Många av flyktingarna var barn. Leo understryker i sitt "Efterord" likheterna mellan de nya barnflyktingarna och de finska krigsbarnen och tillägnar de förra sin bok. Hennes bok kan ses som ett direkt inlägg i den flyktingdebatt som bara något år senare ledde till grundandet av det främlingsfientliga partiet Ny demokrati (Larsmo 2007, 117ff). Samtidigt var Ekorrögon ett led i den våg av vittnesbörd från forna finska krigsbarn som hade börjat redan på 1970-talet. Som vi minns var Annu Edvardsens Det får inte hända igen (1977) en av de första böckerna av detta slag. Just den boken har enligt efterordet gett Leo både faktaunderlaget och impulsen att berätta om sitt eget öde.

Gunilla Bönners Impi från Soumussalmi: finlandsbarn i Sverige 19441945 publicerades 1999 men tillkom redan tio år tidigare i samband med vandringsutställningen "Impi - ett finskt flyktingbarn 1944". Denna bok är ännu mera dokumentärt didaktisk än Leos. Den är berättad i jagform av Impi och bygger på Bönners samtal med det forna krigsbarnet Impi Kupari och en av hennes svenska fostermödrar. Den dokumentära avsikten framgår också (förutom av en historik och en efterskrift) av de bifogade kartorna samt de uppenbarligen autentiska fotografierna och breven.

Bönners version av grundberättelsen skiljer sig genom att börja redan det år då Impi föds och ge stort utrymme åt hennes familjs ålderdomliga sätt att leva i en avlägsen by i norra Finland. Men resan till Sverige och vistelsen i två olika fosterhem dominerar boken. Impi förstår inte svenska när hon anländer men klarar sig ändå bättre än många andra krigsbarn. Hon väljer själv tio år gammal att resa till Sverige och hon tvivlar aldrig på att modern i Finland är hennes riktiga mamma. Fastän hon glömt mycket av sin finska när hon återvänder efter ett och ett halvt år framställs inte återkomsten som problematisk: Impi sätter sig på spishällen och "på trevande finska började jag sjunga" (44).

Ibland skymtar dock en mörkare undertext. Impi berättar på sista sidan att hon fått med sig ett fotoalbum hem av sin svenska fostermamma och att hon i "svåra stunder" bläddrar i detta och "reser" tillbaka till Sverige. "Så har det varit för mig hela livet." (46) Plötsligt anar man att berättelsen kunnat berättas på ett helt annat sätt. Det svåra och smärtsamma har skjutits i bakgrunden, kanske av hänsyn till de små barn som Bönners bilderbok riktar sig till. Det får större utrymme i hennes efterskrift (avsedd för lite äldre läsare) som avslu- 
tas med ett citat från ett annat krigsbarn: "Endast på resa känner jag mig hemma. Hemma längtar jag bort, borta längtar jag hem." (51)

\section{Summering}

Sammanfattningsvis kan man konstatera att de relativt fåtaliga barnböckerna om finska krigsbarn är en mycket kvinnlig genre. Böckerna speglar i hög grad den tid då de skrevs. Under kriget (då all kritik var förbjuden i Finland) uppfattades inte transporterna som problematiska. I de titlar som kom ut under denna första period är perspektivet svenskt och det som står i centrum är viljan att hjälpa och själva mottagandet av barnen - som bara i ett enda fall framstår som konfliktfyllt. Synen på barnet är i dessa böcker överraskande modern: huvudpersonerna är genomgående mognare, klokare och mera ansvarstagande än de vuxna tror.

Problemen med barntransporterna dyker upp på allvar först i de böcker som skrevs under det första efterkrigsdecenniet. I dessa böcker, som speglar den dåtida debatten om återsändandet av barnen till Finland, är perspektivet för första gången flyktingbarnens eget. Här är det en helt annan del av krigsbarnsberättelsen som står i fokus: de smärtsamma separationerna och de svåra återkomsterna. Även i de böcker som skrivits under de senaste decennierna är det dessa upplevelser som satt de djupaste spåren.

Också den långa tystnaden under de följande decennierna är tidstypisk. Under denna tredje period var det (både i den offentliga debatten och i forskarvärlden) i stort sett tyst inte bara om de finska krigsbarnen utan om hela andra världskriget, inklusive Förintelsen. Och när de forna finska krigsbarnen under 1990-talet själva börjar berätta om vad de upplevt, sammanfaller detta med det vid denna tid starka intresset för Förintelsen och de första barnlitterära vittnesbörden från de överlevande judiska flyktingarna (Magda Eggens) och också med samtidens intensiva flyktingdebatter. Rent litterärt går utvecklingen samtidigt från fiktiva skildringar av tidstypisk flickbokskaraktär under perioderna ett och två till den fjärde periodens självbiografier och dokumentära skildringar. Samtidigt blir adressaterna yngre - ett par av titlarna är bilderböcker för mindre barn. I dessa didaktiska böcker, där olika typer av paratexter får intyga sanningshalten, utvecklas hela krigsbarnsberättelsen med alla dess moment. Och det berättas i jagform, inte i tredje person som i de tidigare flickböckerna. Slutet är inte heller alltid lika lyckligt som i dessa.

Barnböckerna om finska krigsbarn är numera få. Efter Impi från Suomussalmi har jag bara funnit en enda, Arja Rohlins betydligt mör- 
kare dokumentärroman Lilla barn (2004), där huvudpersonen till sist tvingas göra en andra resa till Sverige. Men även om barnböckerna är få är krigsbarnen själva inte glömda. De lever i en flod av böcker för vuxna, i filmer (som Klaus Herös Den bästa av mödrar), i TV-dokumentärer och i ett växande antal psykologiska, historiska och litteraturvetenskapliga studier. Men det finns också någonting annat som bidrar till att hålla minnet av dem vid liv: det ständigt växande antalet nya flyktingbarn som varje vecka söker skydd i Sverige.

Biographical information: Ulf Boëthius is a professor emeritus of comparative literature, especially literature for children and youth, at Stockholm University. His latest book is "Jag är ingenting, ett fladder, jag är ung." Barn, ungdom och modernitet $i$ Gustav Sandgrens tidiga författarskap (2004). Contact: u.boethius@telia.com

\section{Bibliografi}

Boëthius, Ulf. "Jag är ingenting, ett fladder, jag är ung." Barn, ungdom och modernitet $i$ Gustav Sandgrens tidiga författarskap. Hedemora: Gidlunds förlag, 2004.

Byström, Mikael. En broder, gäst och parasit: uppfattningar och föreställningar om utlänningar, flyktingar och flyktingpolitik $i$ svensk offentlig debatt 19421947. Stockholm: Stockholm University, 2006.

Bönner, Gunilla. Impi från Suomussalmi: finlandsbarn i Sverige 1944-1945. Rimforsa: Förlaget Blå Fjäril, 1999.

Carlquist, Erik. Solidaritet på prov: finlandshjälp under vinterkriget. Stockholm: Allmänna förlaget, 1971.

Edvardsen, Annu. Det får inte hända igen: finska krigsbarn 1939-45. Stockholm: Askild \& Kärnekull, 1977.

Ekberg, Henrik. "Finländska barn i Västerled". I Henrik Meinander, Finlands historia. 4. Esbo: Schildt, 1999.

Eklund, Sigbritt. Pojken med kepsen. Bromma: Opal, 1986.

Jäderin-Hagfors, Maja. Klassens fosterbarn: berättelse för flickor. Stockholm: B Wahlströms bokförlag. 1941.

Jäderin-Hagfors, Maja. Två små flyktingar: berättelse för flickor. Stockholm: B Wahlströms bokförlag. 1944.

Kavén, Pertti. 70.000 små öden: Finlands krigsbarn. Otalampi: Sahlgren.

Tredje upplagan, kompletterad, 2004.

Konttinen, Aili. När Inkeri kom hem från Sverige. Helsingfors: Söderströms, 1949. 
Käppi, Pentti. "Andra världskriget - finska krigsbarn i Sverige". I Ortmark-Almgren, Sinikka (red). Krigsbarns erinran: snäll, lydig och tacksam. Knivsta: Riksförbundet Finska Krigsbarn, 2003.

Lagnebro, Lillemor. Finska krigsbarn. Umeå: Umeå universitet, 1994.

Larsmo, Ola. Djävulssonaten: ur det svenska hatets historia. Stockholm: Bonnier, 2007.

Leo, Veronica. Ekorrögon. Stockholm: Fripress/Natur \& Kultur, 1990.

Lindgren, Astrid. "Jorma och Lisbet". Astrid Lindgren-sällskapet. Medlemsblad nr 25 (2009): 3-6.

Lundkvist, Anna Lisa. Vägen till Kanarieön. Stockholm: Hugo Gebers förlag, 1945.

Ortmark-Almgren, Sinikka (red). Krigsbarns erinran: snäll, lydig och tacksam. Knivsta: Riksförbundet Finska Krigsbarn, 2003.

Rohlin, Arja. Lilla barn: dokumentärroman. Helsingfors: Sahlgrens förlag AB, 2004.

Räsänen, Eila. Finska krigsbarn: separationsupplevelser i barndomen och konsekvenser i vuxenålder. Stockholm: Delegationen för invandrarforskning, 1990.

Schoultz, Solveig von. Nalleresan. Stockholm: Wahlström \& Widstrand, 1944.

Söderling-Brydolf, Christina. Sirpa: berättelse för flickor. Stockholm: B Wahlströms bokförlag. 1954.

Thorson, Staffan. Barnbokens invandrare: en motivstudie i svensk barn- och ungdomslitteratur 1945-1980. Göteborg: Tre böcker,1987. (Skrifter utgivna av Svenska barnboksinstitutet nr 28).

Unnerstad, Edith. Pikku-Lotta. Stockholm: Fahlcrantz \& Gummaelius, 1941.

Uotila, Ylva. Med namnlapp om halsen: fyra finlandssvenska krigsbarnsromaner. Helsingfors: Helsingfors universitet, 2005.

Virtala, Irene, Tystnaden talar: om finska krigsbarn i skönlitteraturen, Migrationsinstitutet: Web Reports no 5, 2004. 